\title{
Preliminary assessment of the capability of the rumen bacterium, Butyrivibrio fibrisolvens, to utilize fructose polymers for growth
}

\author{
M. Cendrowska, A. Kasperowicz ${ }^{1}$ and T. Michałowski \\ The Kielanowski Institute of Animal Physiology and Nutrition, \\ Polish Academy of Sciences \\ 05-110 Jabłonna, Poland
}

\begin{abstract}
The rumen bacterium Butyrivibrio fibrisolvens was able to grow in vitro when timothy grass fructan, inulin, inulooligosaccharides, sucrose, or fructose was the sole source of carbon in the culture medium, and utilized $89.9,47.7,80.9,87.9$ and $94.5 \%$ of the carbohydrate, respectively. The distinctly lower utilization of inulin than other carbohydrates was accompanied by a considerably lower bacteria count in the cultures. Examination of an extract from bacterial cells showed that its fructanolytic activity was closely related to the carbon source in the growth medium. The number of fructanolytic enzymes synthesized by the bacteria depended on the carbon source in the growth medium.
\end{abstract}

KEY WORDS: Butyrivibrio fibrisolvens, fructans, fructanolytic enzymes

\section{INTRODUCTION}

The bacterium Butyrivibrio fibrisolvens represents a significant part of the microbial population in the rumen and its role in the digestion of such plant carbohydrates as cellulose, xylan, pectin, and starch has been widely studied (Stewart et al., 1997). In contrast, very little is known about the ability of these bacteria to utilize fructans (Ziołecki et al., 1992), which are important storage carbohydrates in grasses and Compositae and consist of fructofuranosyl residues linked by either $\beta-2,6$ (levans) or $\beta-2,1$ (inulins) glycosidic bonds. The objective of this study was, therefore, to examine the ability of $B$. fibrisolvens to utilize various fructose polymers.

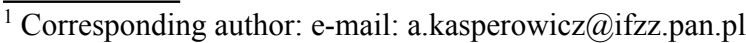




\section{MATERIAL AND METHODS}

Butyrivibrio fibrisolvens strain 3 bacteria isolated from ovine rumen (Ziołecki et al., 1992) were cultured in an anaerobic medium (Hungate, 1969) supplemented with $0.5 \%(\mathrm{w} / \mathrm{v})$ of timothy grass fructan, inulin, inulo-oligosaccharides, sucrose, or fructose as the sole source of energy. The bacteria were grown for $24 \mathrm{~h}$. At the end of the incubation period, the optical density of the cultures was determined by measuring absorbance at $660 \mathrm{~nm}$ and the carbohydrate concentration in the medium was determined by the anthrone method.

The fructanolytic properties of bacteria were evaluated by quantification of reducing sugars released from the particular carbohydrates following incubation $\left(20 \mathrm{~h}, 40^{\circ} \mathrm{C}\right)$ with a cell-free extract in $0.02 \mathrm{M}$ sodium phosphate buffer $(\mathrm{pH} 6.0)$. The cell-free extract was prepared by sonication and centrifugation ( $23000 \mathrm{~g}$ for 15 min at $4^{\circ} \mathrm{C}$ ) of disrupted bacteria.

Reducing sugars were determined using the dinitrosalicylic acid reagent (Miller et al., 1960). Identification of fructanolytic enzymes was performed by native polyacrylamide gel electrophoresis (PAGE) in combination with zymogram (Gabriel and Wang, 1969).

\section{RESULTS AND DISCUSSION}

Bacteria were able to grow on all five carbohydrates used as sole sources of carbon in culture media. The density of the bacterial population grown on inulin and fructose was, however, significantly lower $(\mathrm{P}<0.05)$ when compared with the culture maintained on timothy grass fructan, inulooligosaccharides, or sucrose (Table 1).

Table 1. Bacterial population density (absorbance at $660 \mathrm{~nm}$ ) and substrate utilization (\% of initial content) after $24 \mathrm{~h}$ of incubation of $B$. fibrisolvens on media supplemented with different carbohydrates. Mean values $(n=4)$

\begin{tabular}{lcccccc}
\hline \multirow{2}{*}{ Item } & \multicolumn{5}{c}{ Carbon source in the culture medium } \\
\cline { 2 - 7 } & T.g. $\mathrm{f}^{\mathrm{1}}$ & inulin & I.o.s. ${ }^{2}$ & sucrose & fructose & mean SD \\
\hline Population density & $1.07^{\mathrm{a}}$ & $0.69^{\mathrm{b}}$ & $1.20^{\mathrm{a}}$ & $1.07^{\mathrm{a}}$ & $0.81^{\mathrm{b}}$ & 0.107 \\
Substrate utilization & $89.9^{\mathrm{a}}$ & $47.7^{\mathrm{c}}$ & $80.9^{\mathrm{b}}$ & $87.9^{\mathrm{ab}}$ & $94.5^{\mathrm{a}}$ & 5.75 \\
\hline
\end{tabular}

${ }^{1}$ timothy grass fructan; ${ }^{2}$ I.o.s. inulooligosaccharides

values in rows marked with different letters differ significantly $(\mathrm{P}<0.05)$

The lower number of bacteria growing on inulin was accompanied by significantly restricted utilization of this fructan $(\mathrm{P}<0.05)$. A similar relationship was found earlier in the rumen bacteria, Treponema sp. (Kasperowicz, 2005). 
Utilization of fructose was not, however, lower despite the restricted growth of bacteria on the medium with this carbohydrate. Further studies are thus needed.

Identification of fructanolytic enzymes of $B$. fibrisolvens revealed that their synthesis was closely related to the carbon source in the growth medium (Table 2).

Table. 2 Fructanolytic enzyme activity of the bacterial cell extract in relation to the carbohydrate added to growth medium (nM fructose $/ \mathrm{mg}$ protein $/ \mathrm{h}$ )

\begin{tabular}{lccc}
\hline Carbon source & \multicolumn{3}{c}{ Degraded carbohydrates } \\
\cline { 2 - 4 } in growth medium & T.g. fructan & inulin & sucrose \\
\hline T.g. fructan & 2529.7 & 235.7 & 1563.6 \\
Inulin & 151.2 & 142.3 & 2475.3 \\
Sucrose & 66.7 & 77.1 & 2400.4 \\
Fructose & 6.9 & 18.4 & 213.7 \\
\hline
\end{tabular}

This suggests the inducible character of this protein(s), with the exception of a nonspecific enzyme capable of degrading both the $\beta-2,1$ and $\beta-2,6$ glycosidic linkages in the chain of fructose residues (Uchiyama, 1993). This suggestion is supported by the results of zymography (Figure 1).

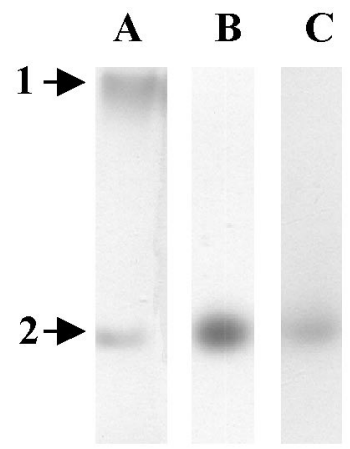

Figure 1. Zymogram of timothy grass fructan (A) and sucrose (B,C) degrading enzymes of Butyrivibrio fibrisolvens bacteria growing in a medium supplemented either with timothy grass fructan $(A, B)$ or sucrose (C). 1- specific enzyme, 2 - nonspecific enzyme

It was found that bacteria growing on the medium with timothy grass fructan synthesized an enzyme specifically degrading this polysaccharide and a second one that was able to digest timothy grass fructan and sucrose. The former enzyme was not, however, present in the cell-free extract when bacteria were grown on sucrose. Thus, Butyrivibrio fibrisolvens strain 3 differs from some strains of ruminal treponemes that synthesize specific and nonspecific fructanolytic enzymes regardless of the carbon source in the growth medium (Kasperowicz, 2005). 


\section{CONCLUSIONS}

Butyrivibrio fibrisolvens strain 3 belongs to species utilizing fructose polymers for growth. The obtained results suggest that it synthesizes an enzyme specifically digesting $\beta-2,6$ glycosidic linkages between fructose residues and also an enzyme splitting $\beta-2,6$ and $\beta-2,1$ linkages. On the other hand, the performed studies suggest that the carbon source present in the medium used for cultivation of bacteria can be the factor inducing the synthesis of some fructanolytic enzymes.

\section{REFERENCES}

Gabriel O., Wang S.-F., 1969. Determination of enzymatic activity in polyacrylamide gels. Anal. Biochem. 27, 545-554

Hungate R.E., 1969. A roll tube method for cultivation of strict anaerobes (IV). In: J.R. Ribbons, D.V. Ribbons (Editors). Methods in Microbiology. Academic Press Inc., New York, Vol. 3B, pp. 117-132

Kasperowicz A., 2005. Characterization of fructanolytic activity of rumen bacteria from the genus Treponema (in Polish). PhD. Thesis. The Kielanowski Institute of Animal Physiology and Nutrition, Jabłonna (Poland)

Miller G.L., Blum R., Glennon W.E., Burton A.L., 1960. Measurement of carboxymethyl-cellulase activity. Anal. Chem. 2, 127-132

Stewart C.S., Flint H.J., Bryant M.P., 1997. The rumen bacteria. In: P.N. Hobson, C.S. Stewart (Editors). The Rumen Microbial Ecosystem. Blackie Academic and Professional, London, Wheinheim, pp. 10-72

Uchiyama T., 1993. Metabolism in microorganisms. In: M. Suzuki, N.J. Chatterton (Editors). Part II. Biosynthesis and Degradation of Fructans by Microbial Enzymes other than Levansucrase. Science and Technology of Fructans. CRC Press Inc., pp. 169-190

Ziołecki A., Guczyńska W., Wojciechowicz M., 1992. Some rumen bacteria degrading fructan. Lett. Appl. Microbiol. 15, 244-247 